Nugroho Nur Susanto

Balai Arkeologi Provinsi Kalimantan Selatan

Jalan Gotong Royong II, RT. 03/06, Banjarbaru

70711, Kalimantan Selatan, Indonesia;

posel: nugi_balarbjm@yahoo.com

Diterima 26 Oktober 2020

Direvisi 21 Desember 2020

Disetujui 22 Desember 2020

\section{DUA PENINGGALAN ARKEOLOGI DI KABUPATEN BULUNGAN: TELAAH MATERIALISME DAN UNSUR ENIGMA}

\author{
THE TWO ARCHEOLOGICAL RELICS IN BULUNGAN \\ REGENCY:STUDYING OF MATERIALISM AND \\ ENIGMA ELEMENT
}

\begin{abstract}
Abstrak. Mengaitkan tinggalan arkeologi dengan humanisme bukanlah suatu hal yang mudah, tetapi menyadari bahwa arkeologi dekat dan bagian dari humanisme adalah suatu keniscayaan. Ada dua peninggalan arkeologi yang memiliki kesamaan, yaitu dikenal karena memiliki cerita yang bercampur dengan mitos, kepercayaan yang tak masuk akal atau dikenal dengan istilah misterius atau enigma. Peninggalan itu adalah batu tegak Lahaibara di Sungai Kayan dan peninggalan Makam Syeh Maulana Maghribi di Sungai Pimping. Secara administratif kedua peninggalan arkeologi tersebut terletak di Kabupaten Bulungan, Provinsi Kalimantan Utara. Melalui metode observasi dan berpikir kontemplasi filsafat perennial digunakan untuk menjelaskan kemisteriusan atau enigma dari peninggalan-peninggalan tersebut. Pesan humanis yang bisa diperoleh bersifat hakiki menyangkut kearifan yang diperlukan dalam menjalankan hidup yang menjadi hakekat dari seluruh agama-agama dan tradisitradisi besar spiritualitas manusia. Peninggalan arkeologi ini perlu dihadirkan dalam rangka mengupas aspek meterialismenya dan berusaha mengulik aspek didaktiknya. Spiritualisme tampaknya dapat menyatu dengan material peningalan arkeologi.
\end{abstract}

Kata kunci: batu tegak Lahaibara, makam syeh Maghribi, materialisme, humanisme

\begin{abstract}
Associating archaeological remains with humanism is not an easy matter, realizing how close archeology is as the part of humanism, however, is a necessity. There are two archaeological relics that have something in common, known for having stories mixed with myths, an absurd beliefs or known as mysterious or enigmatic terms. The relics are Lahaibara upright stone in Kayan River, and tomb of Syeh Maulana Maghribi in Pimping River. Administratively, those archaeological remains are located in Bulungan Regency, North Kalimantan Province. The method of observation and contemplative thinking of perennial philosophical were used to illustrate the mysterious or enigmatic terms of the relics. The humanist message that can be obtained is essential regarding the wisdom needed in living a life which is the essence of all major religions and traditions of human spirituality. These archaeological heritages need to be presented in order to explore its materialistic and didactic aspects. Spiritualism seems to be able to unite with archaeological remains.
\end{abstract}

Keywords: Lahaibara upright stone, tomb of Sheik Maghribi, materialism, humanism

\section{PENDAHULUAN}

Di suatu wilayah, peninggalan arkeologi 'monumental' hampir selalu menjadi perhatian apalagi yang mengandung cerita, kisah atau kepercayaan yang kadang-kadang sulit diterima akal. Logika arkeolog sering kali dipaksa untuk menjelaskan tentang fenomena peninggalan arkeologi monumental tersebut oleh masyarakat. Untuk menuju kepada sebuah simpulan tentang tinggalan arkeologi suatu hal yang tak mudah, dari bukti yang telah kita peroleh seakan-akan "pecahan-pecahan puzzle" ini memerlukan waktu lama untuk menghimpunnya dan harus dilengkapi walaupun data tersebut dari wilayah administrasi yang berbeda. Peninggalan yang dihadirkan terdiri dari tiga peninggalan arkeologi, yang mengandung enigma atau kemisteriusan. Tulisan ini bertujuan menerangkan fenomena terhadap kedua peninggalan arkeologi tersebut dengan kacamata yang berbeda dengan apa yang telah atau sering dilakukan dan dihasilkan oleh pengetahuan 'normal' pada umumnya.

Bangunan dan artefak dari masa lalu, baik yang sudah kita anggap kuno atau belum merupakan peninggalan bekas sisa-sisa aktivitas, atau bukti eksistensi suatu peristiwa atau kejadian. Keberadaannya baik disengaja atau tidak telah meninggalkan jejak yang dapat memberikan pandangan terhadap suatu kejadian atau peristiwa apa yang telah berlangsung. Peninggalan kebudayaan material atau aspek fisik ini yang jelas bersifat natural dapat dilihat dengan mata, sehingga dapat digunakan sebagai bahan kajian. Melalui benda inilah kita mulai berpikir yang kemudian menuju langkah-langkah analisis sebagai pemasok 
pengetahuan dan sumber informasi. Dengan ungkapan lain, bermula dari benda-benda atau materi muncul ide-ide, interpretasi atau pengetahuan yang bersifat abstrak. Dari sisi filosofis cara pandang ini dapat disebut sebagai cara berpikir 'meterialistik'. Dengan demikian, apabila kita tarik pokok 'benang merahnya' ada dua kutub yang berbeda, tetapi saling melengkapi, yaitu materi (konkret) dan ide-ide (abstrak). Di Kabupaten Bulungan ada dua peninggalan arkeologi yang keberadaannya merupakan peninggalan yang kental dengan legenda atau cerita rakyat yang mengandung enigma atau kemisteriusan serta mengandung cerita hagiologi1. Dengan demikian, peninggalan ini menimbulkan pertanyaan yang sulit dijawab dengan akal normal atau suatu pendekatan dan penjelasan benar-benar diterima banyak orang dengan masuk akal.

Definisi arkeologi mengalami perkembanganperkembangan hingga saat ini, termasuk bagaimana arkeologi bersinggungan dengan filsafat atau humanisme. Definisi arkeologi menurut P.H. Subroto, lebih mengacu pada pendapat Robert J. Braidwood yang dirumuskan bahwa arkeologi adalah suatu ilmu yang mempelajari artefak-artefak dan tingkah laku manusia dengan tujuan untuk mengetahui cara hidup. Pendapat ini dianggap lebih maju, karena era sebelumnya diyakini bahwa arkeologi adalah cabang dari sejarah. Alasannya karena arkeologi terkait dengan naskah-naskah kuno, pendapat ini bertumpu pada buah pikir Stuad Pigott (Subroto 1982). Lebih lanjut Subroto mengaitkan arkeologi dengan kaidah-kaidah sains. Sebaliknya arkeologi juga berhubungan dengan humanisme, dimana humanisme diartikan sebagai cabang ilmu pengetahuan yang menempatkan faktafakta empiris ke dalam suatu kerangka kerja yang berhubungan dengan nilai-nilai dan perasaan manusia.

Perkembangan dan perubahan adalah suatu hal biasa, demikian pula titik temu antara ilmu pengetahuan, khususnya arkeologi hubungannya

\footnotetext{
${ }^{1}$ Menurut Jurjani sebagaimana dikutip oleh Montana, hagiologi adalah cerita-cerita yang tak masuk akal yang dialami oleh para wali (orang yang dekat) dengan Tuhan dan ini adalah semacam anugerah atau keajaiban karena keiklasannya. Contoh: seorang wali dapat merubah diri, bepergian ke tempat yang jauh dalam waktu sekejap, dan berbicara dalam berbagai bahasa (Montana 1988)

dengan kefilsafatan. Seorang arkeolog teoritis Anglo-America bernama Allison Wylie mengatakan; selain sebagai studi ilmiah arkeologi telah memiliki kesan penampilan yang membumi, sudah seharusnya memiliki disiplin filosofis yang mendalam. Arkeologi seharusnya mendekatkan pada kefilsafatan sebagai "soul-searching" atau jiwa pencariannya (Wylie 2002). Lebih lanjut disarankan bahwa arkeologi dapat digambarkan sebagai pengetahuan ilmiah yang filosofinya mendekati pada masalah-masalah atau perdebatan-perdebatan antara lain pada naturalisasi filsafat dan masalah sosial humanisme. Pendapat ini walaupun tidak mutlak harus diikuti semua lapisan, tetapi paling tidak dapat memberi warna baru arkeologi jenis lain, disamping pendekatan positivistik yang dapat dipandang 'lebih' ilmiah yang mengacu kepada metode ilmu alam (Wylie 2002). Peninggalan arkeologi dari kedua situs yang akan dikaji, memiliki data fisik selain itu juga mengandung legenda, mitos, cerita dari masyarakat yang telah beredar sebelumnya. Pada saat ini atau akhirnya cerita itu seakan-akan terbukti atau informasi kuno tersebut terulang kembali dengan meninggalkan bukti fisiknya.

Bertolak pada asal mula pengetahuan yang lebih kuno induk munculnya ilmu pengetahuan sejak Yunani Purba yang kemudian menjadi roh ilmu pengetahuan barat, maka ada dua pendekatan yang keduanya memiliki alasan, landasan berpikir dan titik tolak yang berbeda. Kedua, induk pemikiran itu adalah bermula dari Plato dan Aristoteles. Plato berpendapat satu-satunya pengetahuan sejati ialah apa yang disebut episteme, yaitu pengetahuan bersifat tunggal, tak berubah dengan ide-ide abadi. Apabila manusia mengamati benda, objek yang dilihat atau diamati atau bukti-bukti fisik tak lain adalah hanya bayangan dari ide-ide yang pernah dipandangnya dahulu saat jiwa sebelum masuk ke dalam penjara badan jasmaninya. Dengan cara pandang ini, ilmu pengetahuan bersifat apreori, tafsiran sebagai hasil ingatan (Verhaak 1991). Plato, selain dianggap sebagai peletak dasar ilmu pengetahuan barat dapat juga disebut sebagai Bapak Idealisme. la selanjutnya berpendapat bahwa dunia materi merupakan analogi atau ilusi semata yang dihasilkan oleh panca indera. Idealisme pandangan Plato ini terkait dengan hal-hal abstrak, 
yaitu akherat atau ketuhanan, dan agama, karena keduanya fokus pada aspek spiritual dan moral (Rusdi 2013).

Pandangan Aristotelas bertolak belakang menolak anggapan gurunya, Plato. Intuisi atau ingatan diganti dengan abstraksi, dan untuk mencapai pengetahuan tertinggi manusia harus mengamati kenyataan-kenyataan yang beragam dan yang berubah (materi). Pengamatan yang partikular menuju pada yang universal, sambil meneruskan jalan abstraksi yang akan makin meninggalkan yang inderawi melampaui dugaan dan pendapat hingga akhirnya menuju pengetahuan sejati atau episteme. Dengan penjelasan singkat ini, makin jelas Plato menggunakan model ilmu apreori, sedang Aristoteles menyusun langkah suatu model ilmu dengan menggabungkan model apreori dan aposteriori (Verhaak 1991). Kembali kepada pendapat Wylie tentang naturalisasi filsafat, tampaknya sejalan dengan pendapat bahwa ciri khas filsafat ialah mencari sebab pertama, di sisi lain filsafat juga mencari sebab musabab paling akhir ataupun paling dalam.

Dengan rumusan demikian, seakan-akan dapat dikatakan bahwa urusan filsafat dalam arti tertentu jauh dari kehidupan, tetapi sekaligus amat dekat yang berarti gejala-gejala yang kita alami dan yang kita selidiki (Verhaak 1991). Perkerangkaan berpikir di atas selanjutnya akan membawa kita kepada pemahaman dan penjelasan bahwa peninggalan arkeologi yang telah dipilih merupakan jejak masa lalu, yang dapat terhubung dengan kehidupan sekarang dan mungkin dengan masa yang akan datang. Permasalahan yang diangkat dalam artikel ini adalah bagaimana jalan pemikiran dan data atau informasi yang saat ini berkembang, terhadap dua peninggalan arkeologi sekaligus menghubungkan pemikiran dan informasi cerita tersebut menjadi bukti material aspek peninggalan arkeologi yang pada saat ini berwujud atau terbentuk.

\section{METODE}

Metode penelitian ini bersifat observasi, yaitu metode penelitian yang dilakukan dengan cara pengamatan terhadap objek penelitian, yaitu peninggalan masa lalu secara langsung. Berusaha untuk mendapatkan data dan informasi secara mendetail guna menemukan informasi-informasi, fenomena-fenomena mengenai objek yang diteliti. Untuk menuju ke analisis, penulis berusaha menelaahnya dan berpikir lebih mendasar dengan melihat latar belakang cerita, mitos atau kepercayaan masyarakat, serta sumber tertulis. Selanjutnya untuk membuka cakrawala pemikiran yang lebih luas, perlu dihadirkan dasar-dasar filsafati, pemikiran yang bersifat kontemplatif, yaitu menelusuri logika berpikir yang berkembang, dan menghuhubungkan dengan aliran filsafat yang umum dianut secara luas dan yang mempengaruhi perkembangan dunia pemikiran. Objek penelitian ini berupa situs atau cagar budaya yang dapat dikaitkan dengan pemikiran atau teori materialisme, namun demikian bukan berarti terpisah dengan makna humanismenya. Sedangkan adanya unsur aneh, ganjil atau enigma serta unsur hagiologi, dan hal-hal demikian dapat dihubungkan dengan filsafat perennial. Pada perkembangannya arkeologi perlu menyadari bahwa naturalisasi kefilsafatan itu hal yang biasa dan dapat memperkaya daya jangkauan teoritisnya. Secara sistematis mengenai data, gelajagelaja pada objek yang teliti dapat di kontrol keandalan (realiabilitas) dan kesahihannya (validitasnya) secara langsung atau dengan menelusuri kepada sumber-sumber informasi.

\section{HASIL DAN PEMBAHASAN}

\section{Data Arkeologi dan di balik Kisah yang Menyertainya}

Ada dua situs terkait kisah atau kejadian yang memiliki bukti material unik atau ganjil yang umum disebut enigma. Kedua situs secara administratif berada di wilayah Kabupaten Bulungan, Provinsi Kalimantan Utara. Kemunculan dan peristiwa yang menyertai terjadinya situs ini diperkirakan pada periode awal saat masyarakat wilayah ini telah mengenal agama Islam dan kisah yang terjadi berlanjut hingga saat ini yang dapat dikatakan telah memasuki era modern.

\section{Situs Batu Tegak Lahaibara}

Situs Lahaibara secara administrasi terletak di Desa Long Pelban, Kecamatan Long Peso', 
Kabupaten Bulungan. Situs Batu tegak Lahaibara, terletak tidak jauh di sebuah bukit kecil di pinggir sebelah kiri Sungai Kayan atau Sungai Bulungan. Situs ini oleh masyarakat dianggap bersejarah karena terkait dengan hubungan kekerabatan antara suku Dayak Hupan atau Kayan dengan suku Bulungan atau masyarakat Melayu Bulungan. Situs Lahaibara hingga saat ini masih dihormati oleh kedua belah pihak, karena berhubungan dengan batas teritorial saat mereka memutuskan untuk berpisah. Intensitas kepercayaan terhadap situs ini pun kian memudar seiring dengan pemikiran yang makin terbuka dan sudah tidak relevan lagi dari sudut modernisme. Secara administrasi kewilayahan pemerintahan modern pun, batas ini tentu tak lagi berlaku.

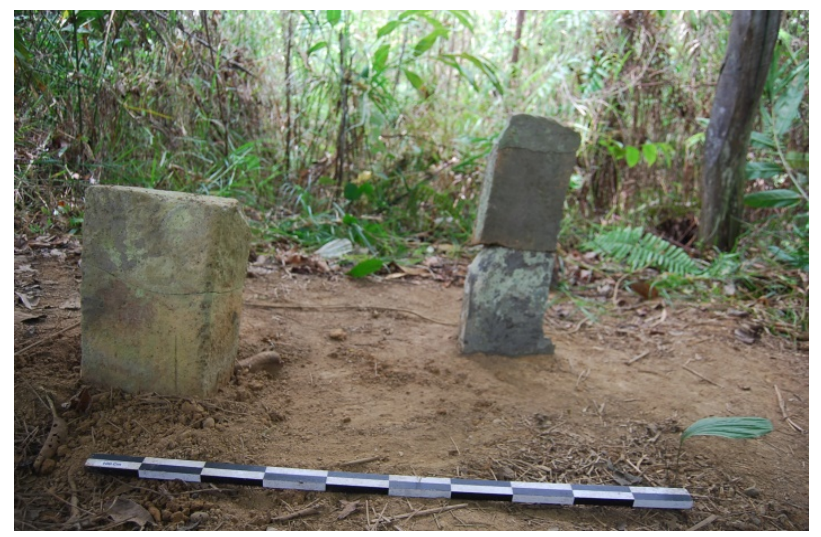

Sumber: Balai Arkeologi Kalsel 2012

Gambar 1 Dua buah 'Batu tegak' Lahai Bara, Batas

Demarkasi Teritorial Masyarakat Bulungan dan Komunitas Kayan/Hupan

Mitos yang beredar mengisahkan komunitas besar ini bermula dari keluarga Kuanyi, berlanjut ke dua tokoh mistis Juawiru-Lemlai Suri, yang kemudian menurunkan Parang Anyi, Jau Anyi. Setelah generasi Parang Anyi, Jau Anyi kemudian baru melahirkan seorang tokoh bernama Lahaibara yang menikah dengan Wan Paren. Jau Anyi sebelum meninggal, berpesan kepada Lahaibara untuk membawa lungunnya (lungun= peti mati dari kayu) ke hilir. Tokoh Lahaibara berhasil membawa lungun yang berisi jenazah Jau Anyi) tersebut menuju ke hilir sungai untuk membentuk komunitas baru. Tokoh Lahaibara, menjadi awal perubahan dimana ia berusaha keluar dari komunitasnya dan kemudian berkenalan dengan masyarakat yang mengenalkan agama Islam, dan mendirikan Kesultanan Bulungan pada generasi-generasi berikutnya (Susanto 2012b; Muh.Zarkasi 2010). Adapun apa yang menjadi permasalahan adalah latar belakang rusaknya peninggalan batu tegak di situs Lahaibara². Pengerusakan ini adalah ulah seorang opsir Belanda, sumber lain manyatakan sebagai controliur bernama Mayer yang kesal dengan pengantar priyayi Bulungan, saat mereka sudah tidak lagi bersedia melewati batas 'tugu batu tegak Lahaibara' saat menuju ke arah hulu sungai sewaktu survei mencari informasi kekayaan alam wilayah Kesultanan Bulungan bagian hulu Sungai Kayan. Keengganan ia bukan tanpa sebab, karena mereka masih mempercayai bahwa tanda 'tugu batu tegak' Lahaibara ini adalah batas demarkasi wilayah teritorial adat antara masyarakat Bulungan dengan daerah komunitas Dayak Hupan/Kayan, saudara tuanya. Rupanya Mayer marah besar dan tidak mempercayai hal mistis ini apalagi tentang komitmen, janji, atau sumpah peraturan adat tersebut. Maka, dirusaklah tugu batu tersebut, diantaranya menjadi tiga bagian. Tan Alui, mengisahkan peristiwa pengrusakan atas tugu batu itu terjadi kira-kira pada tahun 1921. Mayer mengira dengan tindakan tersebut akan melemahkan

\footnotetext{
2 Saat penulis ke lokasi tahun 2012, hanya ada balok batu-balok batu yang kondisinya berserakan, dan pecah secara beraturan. Kemudian penulis rangkai ternyata menjadi dua sosok batu tegak, satu batu andesit terdiri atas tiga bagian (cocok dengan tragedi Mayer) dan satu buah balok batu putih yang pecah menjadi 2 bagian. Sehingga ada dua buah tugu batu yang diasumsikan sebagai nisan makam atau mungkin sebuah menhir. Adapun patung batu, sebagaimana Udau informasikan saat itu sudah tidak ada di tempat (Susanto 2012a). Tetapi, apabila melihat arah orientasi kedua tonggak batu utara-selatan sangat dimungkinkan objek ini adalah makam, tetapi juga tidak tertutup kemungkinan sebuah menhir. Permasalahan siapa yang dimakamkan juga sulit dijawab, apakah makam Lahaibara atau makam Jau Anyi, orang tua Lahaibara yang meminta ia dikuburkan di daerah hilir. Belum ada penjelasan ilmiah ke sana. Balok batu I mirip nisan yang berbentuk, persegi panjang yang telah terpotong bagian atasnya. Ukuran tinggi yang tersisa 45 centimeter, lebar 30 centimeter, dan tebal 18 centimeter, Balok Batu 1 ini patah menjadi 2. Batu tegak ini terbuat dari batu putih.Balok batu tegak II atau nisan II berada pada jarak 64 centimeter, terbuat dari batu andesit dan terletak di sisi barat daya dari nisan I (balok batu I. Batu ini berbentuk balok persegi panjang yang telah terpotong menjadi 3 bagian. Setelah disambung, ukuran panjang tinggi 64 centimeter dengan lebar 20 centimeter dan tebal 12 centimeter. Batu tegak ini pecah menjadi 3 bagian, hal ini cocok dengan keterangan Tan Alui, saat peristiwa di tahun 1921-an. Masyarakat Mangkulit menceritakan dahulu ada dua buah figur patung yang telah dicuri ditahun 1990-an kedua patung figur terletak di depan masing-masing balok batu tegak tersebut.
} 
kepercayaan mistis dan dapat segera melanjutkan tugasnya. Tidak lama setelah peristiwa itu, Mayer pun jatuh sakit dan akhirnya meninggal secara mengenaskan (Susanto 2012a).

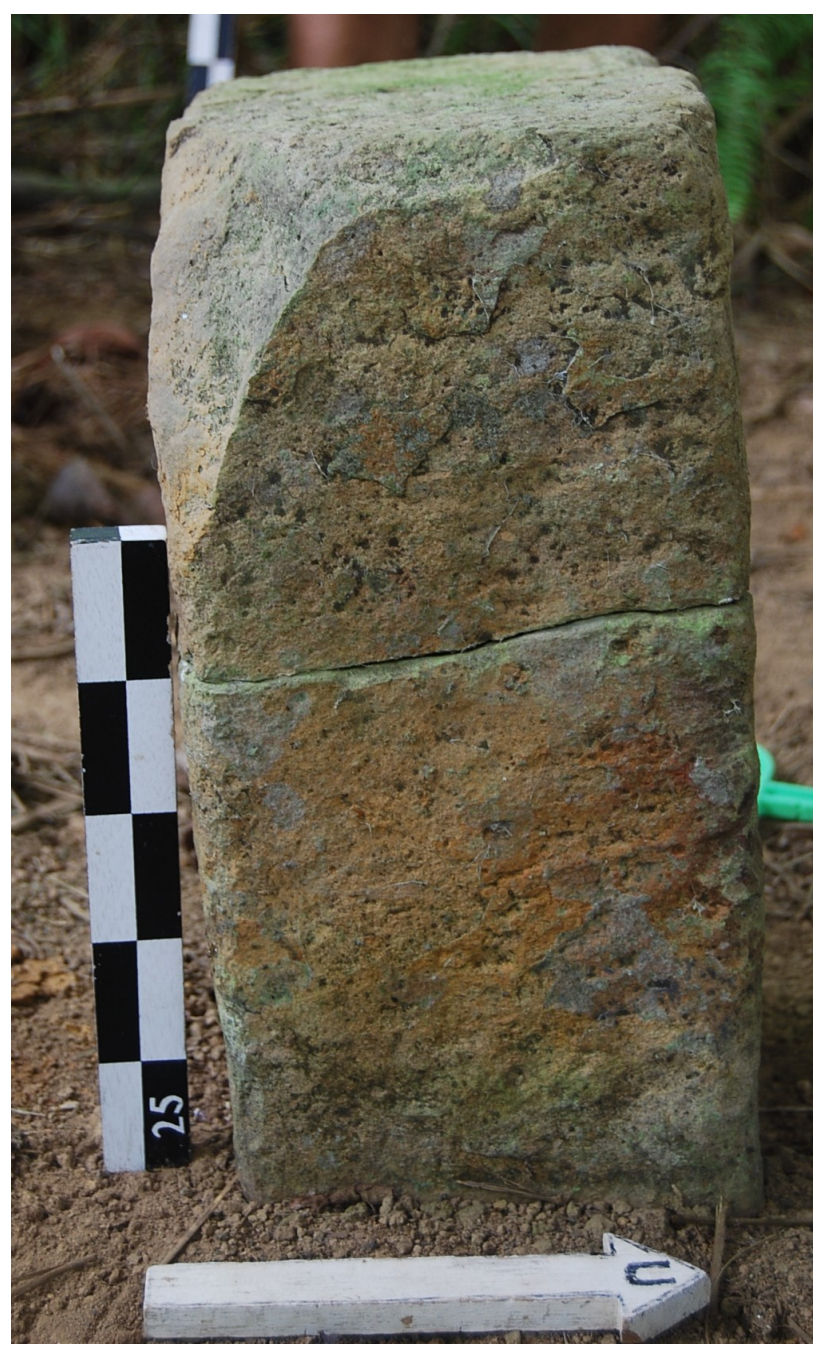

Sumber: Balai Arkeologi Kalsel 2012

Gambar 2 'Batu tegak' Lahai Bara, yang telah dirusak saat Belanda mengadakan survei di tahun 1921

\section{Makam Syeh Said Ahmad Al-Maghribi dan} Jembatan Pimping

Kompleks makam Said Maulana Ahmad AlMaghribi berada di Desa Salim Batu Kecamatan Tanjung Palas Timur, Kabupaten Bulungan, Provinsi Kalimantan Utara. Komplek makam ini terletak di lereng tebing sungai yang berada di sebelah barat aliran Sungai Pimping yang bermuara di Teluk Sekatak. Sungai ini merupakan bagian hilir Sungai Bulungan atau Kayan. Tokoh utama yang dimakamkan di dalam cungkup bernama Syeh Said
Maulana Ahmad Al Maghribi yang memiliki dua nisan makam dan inskripsi dengan catatan baru, berangka tahun meninggal $1832 \mathrm{M}$. Ada dua makam lain, yang satu bernama makam Datu Iskandar, salah satu murid Syeh Said Maulana dan makam yang lain tidak disebutkan identitasnya. Selain ketiga makam di dalam cungkup utama, terdapat juga makam lainnya yang tersebar di sekitar cungkup pada lereng-lereng bukit. Kompleks makam berpagar dan terdapat papan nama terkait dengan nama komplek makam dan undang-undang yang melindungi keberadaan situs ini.

Pada tahun 2000 saat penulis untuk pertama kali mendata komplek makam ini lingkungan masih tampak alami dan relatif sepi, walaupun makam ini sering dikunjungi peziarah. Pada tahun itu wilayah ini masih menjadi bagian dari Kecamatan Tanjung Palas, Kabupaten Bulungan Provinsi Kalimantan Timur, daerah ini disebut pula sebagai Bukit Keramat (Atmojo 2000). Pada saat itu tidak tampak ada proyek fisik mencolok, apalagi pembangunan infrastruktur. Pada saat penelitian kedua, di tahun 2012 keadaan berubah, kawasan ini lebih maju, permukiman penduduk bertambah dan penziarah masih ada yang berkunjung, walaupun tidak banyak. Yang tak luput dari perhatian penulis adalah proyek pembuatan infra struktur berupa jembatan yang mangkrak alias terbengkalai. Menurut sumber yang berhasil dihimpun penulis, pembangunan jembatan ini dimulai pada tahun 2008 dan telah berhasil dibangun satu sisi jembatan. Akan tetapi untuk sisi jembatan yang terdapat komplek makam, pembangunan tiang pancang gagal didirikan. Berbagai upaya telah dilakukan saat pendirian tiang pancang, sekalipun telah ditambahkan tonase kekuatan dengan beban lebih, yang semula lima ton dan kemudian dilipatgandakan menjadi sepuluh ton, tetap saja tidak berhasil (Susanto 2012a). Enigma atau mesteri apa yang menyebabkannya, sampai sekarang belum terjawab. Seakan kemisteriusan menyelimutinya.

Siapa sebenarnya Syeh Said Ahmad AlMaghribi? Oleh masyarakat Bulungan dipercaya la adalah penyiar agama Islam awal di Bulungan, khususnya saat pusat pemerintahan di daerah Salim Batu. Tokoh yang sangat dihormati ini menurunkan ulama-ulama atau pendakwah agama Islam di Kesultanan Bulungan, diantaranya Said Ahmad Bil 
Fakih. Syekh Ahmad Al Magribi diperkirakan semasa pemerintahan Wira Amir atau Amiril Mukminin Sultan Bulungan. Selain sebagai pendakwah, peran Syeh Maulana Ahmad Maghribi adalah saat membantu mengusir bajak laut berkat kecerdasan dan ketangkasannya (Bulungan 2010). Nama Al Mahgribi ini mengacu pada daerah asal Said Ahmad yang kemungkinan berasal dari daerah Mesir, Libya atau Aljazair. Situs ini telah ditetapkan sebagai Cagar Budaya oleh Kabupaten Bulungan sejak berdasar Undang-Undang Nomor 5 tahun 1992. Cerita yang beredar di masyaraat tampaknya sulit dipercaya oleh akal yang juga pertanda ia adalah tokoh yang memiliki kedudukan ilmu yang tinggi. Konon, saat ia dimakamkan waktu sudah menjelang senja, tetapi seakan matahari pun menunggu tidak tenggelam sebelum prosesi pemakaman selesai. Wawancara penulis dengan juru kunci makam tahun 2000.

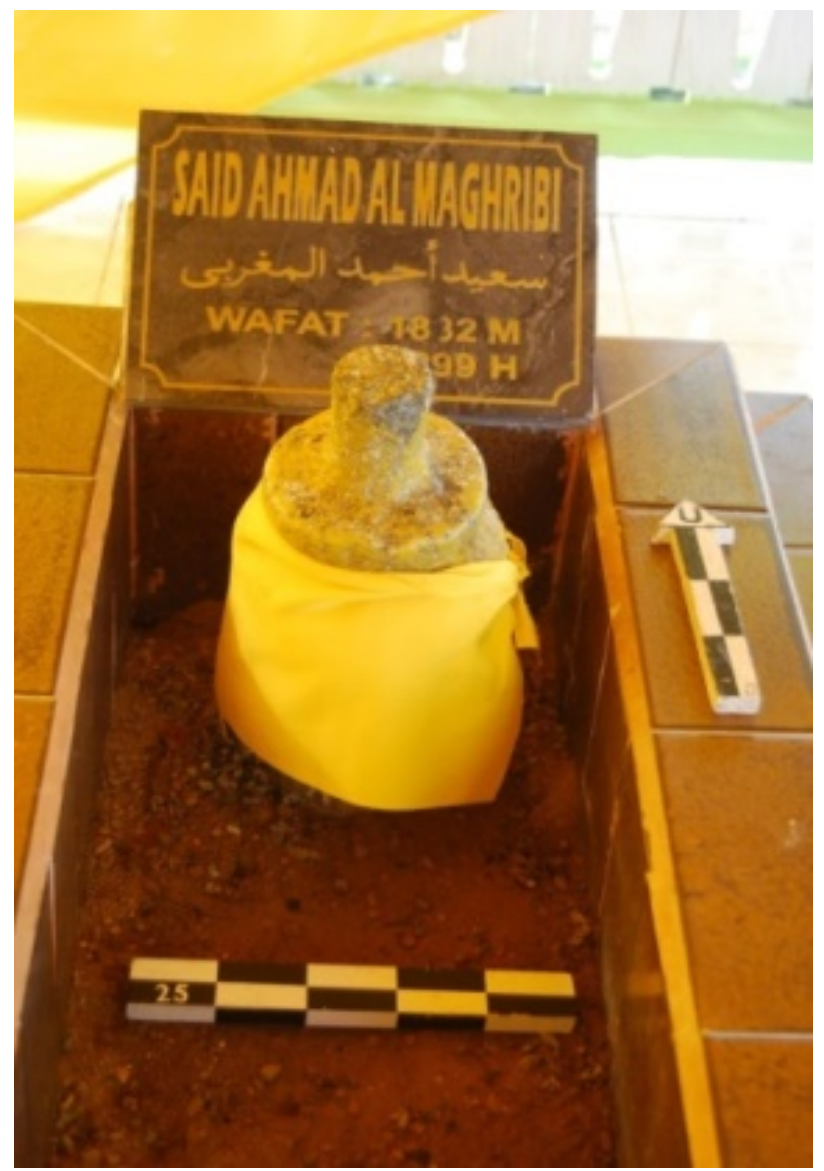

Sumber: Balai Arkeologi Kalsel 2012

Gambar 3 Nisan Makam Habib Syeh Ahmad Al Maghribi yang Merupakan Penyiar Agama Islam Bulungan Awal

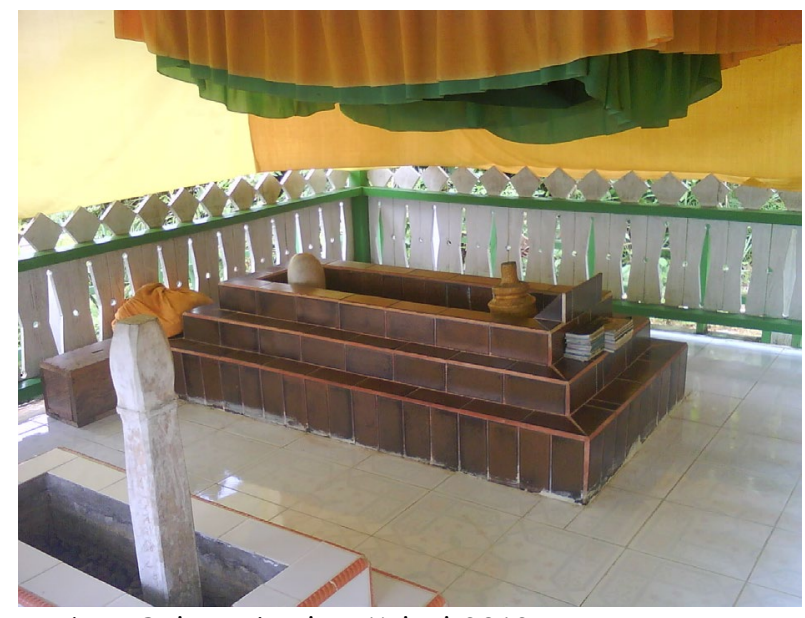

Sumber: Balai Arkeologi Kalsel 2012

Gambar 4 Makam Habib Syeh Ahmad Al Maghribi yang dimakamkan di Bukit Keramat, dekat Sungai Pimping

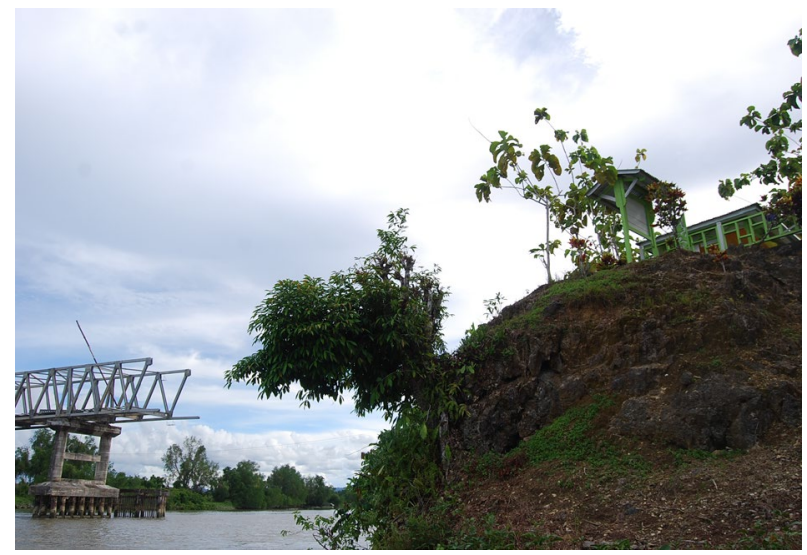

Sumber: Balai Arkeologi Kalsel 2012

Gambar 5 Proyek Pembangunan Jembatan Sungai Pimping yang Dimulai Tahun 2008-2010 yang Mangkrak Dilihat dari Bagian Bawah Sungai

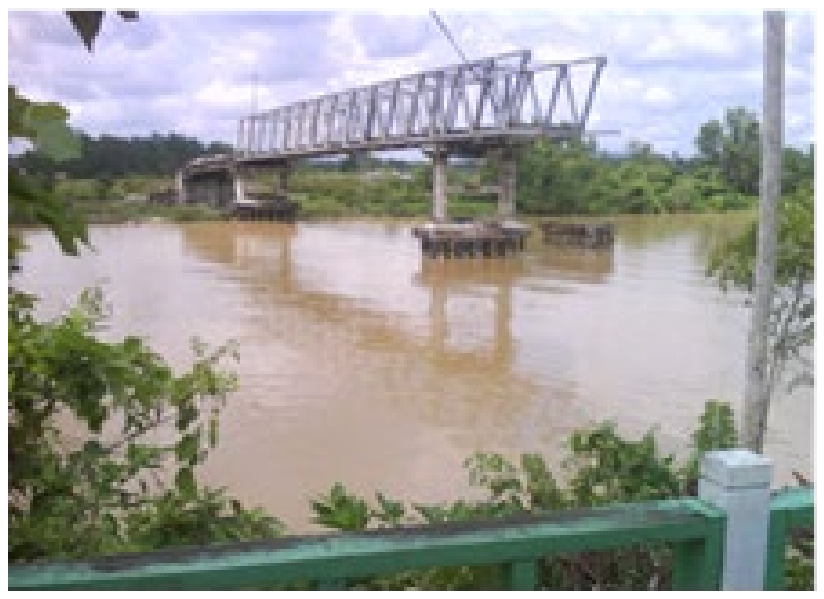

Sumber: Balai Arkeologi Kalsel 2012

Gambar 6 Proyek Pembangunan Jembatan Sungai Pimping yang Dimulai Tahun 2008-2010 Dilihat dari Kompleks Makam 


\section{Pembahasan}

Peninggalan arkeologi dan penelitiannya memiliki andil besar dalam upaya-upaya menemukan dan mengkaji sumberdaya arkeologi atau cagar budaya sebagai kekayaan suatu bangsa. Di sisi lain sumberdaya jenis ini memiliki sifat-sifat langka, mudah rusak, unik dan tak dapat diperbaharui. Secara yuridis UU Nomor 11 tahun 2010 tentang Cagar Budaya, cagar budaya dapat diajukan minimal telah berumur 50 tahun, dalam kasus tertentu hal ini dapat diabaikan. Sebagai kajian material culture masa kajian umur benda tidak harus terpaut jauh dengan masa sekarang, tetapi meliputi pula kejadian beberapa tahun yang lalu, puluhan hingga ratusan, bahkan ribuan tahun yang lalu. Pokok pola pikir ini dipegang teguh oleh semua arkeolog mulai dari tingkat amatir hingga arkeolog ilmuwan profesional. Arkeologi memunculkan bukti sisa-sisa masa lampau digunakan dalam upaya mengambarkan peristiwa masa lampau dan menjelaskan tingkat laku manusia dibalik peristiwaperistiwa (Sharer 2003)

Sebagai sebuah disiplin ilmu, arkeologi mendasarkan pada filosofi cara kerja yang menekankan pada perlindungan, pelestarian serta mengelolaan manfaat dari sumberdaya budaya bendawi tersebut bukan saja untuk saat ini, tetapi jauh ke depan untuk generasi yang akan datang, demikian William J. Mayers mengutip pendapat Mc Gimsey \& Davis, 1977. Adigium yang perlu terus dipegang teguh adalah "kita harus melestarikan peninggalan sumberdaya arkeologi apabila kita ingin mendapat manfaat darinya, kita harus mempelajarinya jika kita ingin memahaminya, dan kita harus menyampaikan pengetahuan yang kita peroleh tersebut kepada masyarakat luas". Demikian William J. Mayers- Oakes menginginkan bahwa tangungjawab tersebut sangat perlu dimiliki oleh setiap arkeolog (William J. Mayers- Oakes 1989).

P.H. Subroto mengutip pendapat Nicola Abbagnano secara lugas mengatakan bahwa humanism adalah suatu filsafat yang mengakui nilainilai dan martabat manusia. Pengetahuan humanisme bersifat ideografis artinya mempelajari benda-benda atau kejadian secara individual dari dan untuk kepentingan benda dan kejadian itu sendiri (Subroto 1982). Dengan demikian la menganggap kehadiran pandangan humanisme tidak terlalu dipermasalahkan, sekalipun memiliki tingkat akurasi kebenaran kurang atau sulit dipermasalahkan. Menurut M. Fagan awal mula kemunculan arkeologi tidak terlepas dari pertanyaan tentang bagaimana manusia pertama dan bagaimana awal mula dunia diciptakan. Arkeologi terletak di antara dua kutub bidang yang berseberangan, yaitu legenda, mitos, dan tugas 'rekontruksi teori ilmiah' sebagaimana dituntut atau dialami masyarakat modern (Fagan 1991; Susanto 2000). Julian Thomas juga menyarankan untuk arkeolog memperhatikan perkembangan akar pemikiran dunia barat dan mengakaitkan dengan proyek kemoderenan dengan proporsional. Arkeologi menyelidiki masa lalu melalui media materi. Namun demikian, makin jelas bahwa ilmu ini tidak sekedar hanya merekonstruksi tanpa mengkaitkan kepada hal-hal yang lebih mendasar dengan kehidupan. la setuju dengan gagasan Gadamer bahwa 'merekonstruksi; adalah berusaha membangun hubungan antara masa lalu dan masa sekarang. Hubungan ini dapat dipahami sebagai semacam percakapan, kepada yang kita bawa berbagai macam harapan dan prasangka, dan dari mana kita menerima tantangan itu. Lebih jauh Julian Thomas menegaskan bahwa data arkeologi dan masa lalu tidak pernah sepenuhnya mengungkapkan dirinya sendiri kepada kita, tetapi diperlukan melalui keterlibatan yang berkelanjutan, belajar lebih banyak, baik tentang dunia masa lalu dan tentang diri kita sendiri. Pengakuan diri yang muncul dari proses ini melibatkan peningkatan kesadaran akan asumsi-asumsi dari kita sendiri dan prasangkaprasangka sebagai 'bagasi' konseptual informasi, data dari masa ke masa, bukan sesuatu yang dipaksakan (Thomas 2004).

Julian Thomas mengingatkan bahwa menghubungan arkeologi dengan aliran marxisme harus disikapi dengan hati-hati. Unsur-unsur pemikiran kefilsafatan dan cara kerja demikian harusnya menjadi pengetahuan bagi arkeolog dalam menjalankan tugasnya. Perhatian untuk mengkaji kontribusi arkeologi Marxis terhadap pemahaman sosial dan hubungan ideologis harus dibedakan. Perlu mempertimbangkan struktur sosial di konteks ini, dan kontras dengan pendekatan prosesual yang perlu diidentifikasi lebih lanjut. Dalam persoalan 
struktur sosial tidak berarti sama dengan pola peran dan hubungan pemikirannya, untuk mengacu pada skema interaksi produktif mungkin dapat diterima di balik peninggalan-peninggalannya dengan era industri (Thomas 2004). Hal ini juga disepakati sebagaimana telah arkeolog lain seperti Spriggs dan Trigger sebagaimana dikutip oleh Julian Thomas. Perhatian mereka di sini bukanlah untuk memperdebatkan sepenuhnya arkeologi Marxis, yang selama ini telah berlangsung cukup tertutup. ${ }^{3}$

Dengan melihat hal-hal demikian, ilmu arkeologi memiliki dasar-dasar berpijak, sejauhmana jangkauan, orientasi dan potensinya yang memiliki

\footnotetext{
${ }^{3}$ Dalam aliran arus filsafat pemikiran filsuf G.W.F. Hegel dan para filsuf sebelumnya mengatakan bahwa ide absolut adalah Tuhan yang berkembang dalam sejarah dan mengungkapkan dirinya dalam alam dan manusia. Pemikiran fundamental Hegel dengan Teori Dialektikanya justru seakan menyudahinya, ketika menempatkan tesis-antitesis-sintesa sebagai pokok pemikirannya, sehingga salah satu murid terkenal Marx menjadi fenomenal. Kembali pada idealisme, bahwa idealisme adalah falsafah yang berpendapat bahwa dunia ide dan ide adalah inti realitas. Realitas sebenarnya tidak hadir dalam obyek material, tetapi ada pada pikiran dan ide. Idealisme memandang bahwa sang esensi itu adalah ide. Idealisme tetap mengakui keberadaan materi, namun menurutnya yang utama adalah dunia gagasan, Wujudnya abstrak karena gagasan pertama ada sebelum materi. Filosofi ini lalu memberikan implikasinya bagi bidang pendidikan. Filosofi ini membentuk bangunan sebuah pemahaman bahwa pendidikan ditopang berdasarkan ide-ide yang menekankan penalaran abstrak dan moral (Rusdi 2013).

Di sisi lain, hingga Feurbach berpendapat yang dengan buah pikirannya mempengaruhi Marx yang mengatakan bahwa yang absolut itu adalah alam, bukan Tuhan seperti dikatakan Hegel. Marx mengambil tesis Feurbach untuk merasionalisasikan kritiknya terhadap agama dan melakukan transisi dari idealisme Hegel menuju materialisme. Dengan menyatakan bahwa, yang absolut sebenarnya tidak lebih dari sekedar refleksi materi. Lebih jauh, meterialisme dialektika Marx ini bermula pada asumsi bahwa ketidaktergantungan material terhadap immaterial yang dapat membentuk simpulan bahwa tidak ada yang Maha. Aspek-aspek kehidupan yang bersifat ruhanial dianggap bukan hal yang penting, bahkan akan dianggap tidak benar ketika tidak dapat dibuktikan dengan empiris (Pamardiningtyas 2019). Oleh karena itu materialisme seringkali dianggap sebagai faham yang anti terhadap keberadaan Tuhan. Feuerbach menunjukkan dan telah pada simpulan bahwa Tuhan itu merupakan subjektivitas absolut murni dari manusia sendiri, Tuhan tak lain adalah proyeksi dari kemanusiaan manusia sendiri (Hasiholan). Pemikiran materialisme ini menjadi awal revolusi kebudayaan, yaitu ketika manusia mulai membentuk asas kehidupan dengan cara-cara baru. Berbeda dengan era sebelumnya yang pernah dikenal kehidupan manusia, yang pada mulanya mendasarkan pada sistem kepercayaan dan digantinya dengan pendekatan akal dan direfleksikan ke unsurunsur alam sebagai materi penyusun kehidupan (Pamardiningtyas 2019).
}

posisi sentral dengan penghidupan. Dengan jangkauan kronologis yang panjang dan sebaran data temuan yang sangat luas, ilmu ini memungkinkan berguna dalam memahami dan menjadi sumber pengetahuan tentang hakekat kehidupan manusia. Secara teoritis filsafat idealisme dan materialism sekilas perlu diperkenalkan untuk memperkaya cakrawala berpikir dalam arkeologi, sejauh tidak memasuki ranah sensitif perpecahan dalam masyarakat.

Dalam dunia pemikiran dan ilmu pengetahuan, ada aliran Materialisme yang dipelopori oleh Hegel dan Karl Marx yang mungkin dapat dihubungkan dengan 'materialme' (m huruf kecil) yaitu bukti benda-benda peninggalan, warisan budaya masa lalu, sisa-sisa aktifitas kehidupan terdahulu seperti halnya yang dianut atau sebagai 'alat bantu utama' dalam menafsirkan, menganalisis kehidupan manusia masa lalu di dalam dunia ilmu arkeologi. Namun demikian 'meterialisme' di sini bukanlah satu-satunya metode untuk menemukan pengetahuan, walaupun unsur materi menduduki peran sentral. Metode analisis arkeologi berikutnya antara lain, melalui penelitian lanjutan seperti analisis laboratoris, eksperimen dan permodelan.

Dalam Materialisme, realitas terdiri dari materi yang berarti setiap benda dan kejadian merupakan proses material, Pamardiningtyas mengacu ke Applebaum, bahwa materialisme mendasarkan pada konsep bahwa dunia terdiri dari objek material yang berinteraksi satu dengan yang lain dalam berbagai tingkatan pergerakan. Lebih lanjut diperkuat oleh Wolfe, Materiaisme merupakan proses menghilangkan hal-hal yang berbau mistis dan teori dari kenyataan yang mengaplikasikan kualitas fisik terhadap segala aspek kenyataan. Materialisme mengutamakan semua yang dapat dijamah akal budi dan fenomena selalu dapat dijelaskan dengan ilmu pengetahuan (Pamardiningtyas 2019).

Antara filsafat Idealisme versus filsafat materialisme seakan teruji pada tiga kasus peninggalan budaya ini. Filsafat idealisme berkembang dengan pesat, karena telah dirintis dan di dukung dengan keyakinan kuat, yang penekanan pada kebenaran yang tak berubah, mempunyai pengaruh yang sangat luas. Idealisme adalah sebuah pemikiran filosofis yang telah memberikan pengaruh besar terhadap dunia pendidikan 
beberapa abad silam (Rusdi 2013). Dalam dunia pemikiran moden, idealisme ditumbuhkembangkan oleh tokoh-tokoh seperti Rene Descartes (15961650), George Berkeley (1685-1753), Immanuel Kant (1724- 1804) dan George Hegel (1770- 1831). Tokoh idealisme yang menerapkan gagasangagasan idealisme pada pendidikan modern di antaranya adalah J. Donald Butler dan Herman $\mathrm{H}$. Horne. Sepanjang sejarahnya, Idealisme terkait dengan agama, karena keduanya sama-sama berfokus pada aspek spritual dan moral (Rusdi 2013).

Sebagian filsuf berpandangan bahwa pengetahuan murni dapat diperoleh melalui rasio manusia, aliran ini dirintis oleh Rene Descartes. Aliran ini beranggapan pengetahuan sejati bersifat a preori, pengetahuan bersifat transendental mengatasi pengamatan empiris yang bersifat khusus dan berubah-ubah (Hardiman 1990 dalam Samsuri 2003). Pada sisi lain, aliran empirisme mengutamakan peran pengalaman empiris. Aliran ini berpendirian bahwa pengetahuan sejati hanya dapat diperoleh melalui pengamatan terhadap objek pengetahuan. Oleh karena itu pengetahuan bersifat aposteriori. Konflik kedua aliran pada gilirannya berpuncak pada pembersihan pengetahuan dari kepentingan-kepentingan manusiawi. Auguste Comte, sebagai tokoh utama positivisme mengabaikan dua tahap pemikiran lain yang telah disusunnya sendiri, yaitu tahap teologis dan metafisis. Positivisme menegasikan pengetahuan yang melampaui fakta, yakni dengan mengakhiri riwayat ontologi atau metafisika, karena ontologi menelaah apa yang melampaui fakta inderawi (Hardiman 1990 dalam Samsuri 2003).

Bukti fisik situs, artefak, atau monument di satu sisi dan ide, mitos, kisah hagiologi, di sisi tampaknya dapat dihubungkan dengan 'dunia' pendidikan atau pesan moral. Seakan-akan menyadarkan kepada kita bahwa situs-situs sebagaimana di kemukakan di atas yang terletak di Kabupaten Bulungan, Provinsi Kalimantan Utara, dapat dikaitkan dengan pemikiran-pemikiran, kekayaan sumberdaya budaya, atau peninggalan arkeologi sekaligus warisan masa lampau yang bermakna. Secara fisik dan kejadian apa yang telah disebutkan di atas telah menyedot perhatian masyarakat. Sebagai disiplin ilmu pengetahuan arkeologi dapat diselami dari aspek aksologi, ontologi dan epistemenya.

Pada perkembangan sebagai disiplin ilmu pengetahuan ilmiah, arkeologi banyak menggunakan eksplanasi deduktif-nomologikal sebagaimana cara berpikir Carl Gustav Hempel. Hempel mengemukakan eksplanasi deduktif-nomologikal adalah merupakan langkah yang seharusnya apabila ilmu tentang masa lampau atau kejadian yang dianalisis dapat dianggap sebagai pengetahuan ilmiah. Dimana pengetahuan ini juga diterapkan pada ilmu-ilmu alam lainnya. IImu pengetahuan yang diidam-idamkan manusia adalah bukan sekedar sekumpulan fakta terpisah yang tidak saling berhubungan, tetapi ilmu yang dibangun ditujukan untuk mengeksplanasi fakta-fakta atau data, sehingga fakta-fakta dan data tersebut kedudukannya jelas di dalam struktur pengetahuan manusia. Fakta-fakta dan data tersebut jelas-jelas mempunyai berkedudukan sebagai bukti atau pun bahan yang memungkinkan untuk ditarik sebuah generalisasi (Magetsari 2000).

Eksplanasi deduktif-nomologis ini mulai popular dalam ilmu sosial humaniora semenjak David Hume dan August Comte mengatakan bahwa satu-satunya metode yang dapat diandalkan untuk mendapatkan pengetahuan adalah mengikuti metode ilmu alam. Eksplanasi deduktif-nomologis merupakan penjelasan-penjelasan dengan karakteristik antara lain berasal dari logika formal, ada konfirmasi antara hukum dengan fakta, mendasarkan pada hukum sebab-akibat, dapat menerangkan dengan peristiwa sejenis, tidak mengatakan apapun tentang subjek yang memberi penjelasan, tidak tergantung pada sisi waktu, dahulu, masa kini dan masa yang akan datang. Pola hukum umum atau ungkapan universal, namun kondisial artinya, dapat dibenarkan atau dibantah menurut pengamatan empiris, demikian garis besar yang Hempel inginkan. Ankersmith mengemukakan bahwa pola hukum umum yang digunakan pada ilmu humaniora, khususnya sejarah dalam eksplanasinya memiliki jangkauan yang terbatas, jarang dapat dipakai secara penuh dalam penjelasan fakta historis (Santoso dan Wijaya 2003).

Adapun eksplanasi deduktif-nomologis menurut Ernest Nagel mengisyarakatkan bahwa ilmu sejarah (atau studi yang mendasarkan pada 
kelampauan) tidak semata-mata sebagai ilmu ideografik, yaitu ilmu yang hanya berkaitan dengan sesuatu yang khusus dan tunggal; namun juga bersifat sebagai ilmu nomotetik, berkaitan dengan sesuatu yang umum dan universal. Kecenderungan lebih besar ke arah ilmu ideografik ini muncul akibat anggapan perbedaan struktur logis, konsep dan eksplanasi dalam ilmu sejarah yang berbeda dengan ilmu alam, khususnya. Objek penelitian sejarah bersifat unik dan sekali terjadi, penelitian harus berangkat dari kejadian konkret dan menggunakan istilah umum, sebagaimana yang dipakai pada ilmu alam dan ilmu sosial. Tugas sejarawan dan ilmu kelampauan bukan hanya mencatat rentetan kejadian masa lampau dan memusatkan perhatian pada kejadian tertentu namun juga berusaha untuk memahami dan mengeksplanasi kejadian-kejadian yang dikaitkan dengan hukum sebab akibat, mencari hubungan ketergantungan kausal dalam beberapa kejadian yang berurutan (Santoso dan Wijaya 2003).

Tugas sejarawan dan pengkaji arkeologi bertujuan untuk menegaskan pernyataan tunggal yang benar tentang kejadian dan antar hubungan tindakan kejadian tertentu. Tugas tersebut dapat dicapai sekalipun dalam bentuk asumsi-asumsi dan hukum umum, dan mereka memandang bahwa peran ilmu tersebut tidak bertujuan untuk menemukan hukum demikian pendapat Nagel, di tahun 1974 dikutip Santoso (Santoso dan Wijaya 2003). Pada kutub yang berbeda positifisme logis berhadapan dengan filsafat perennial, yang menganggap akan ada faktor massa dan hakekat dalam perjalanan waktu manusia akan jauh dariTuhan dan perubahan ini dilihat sebagai dinamika. Ada tiga prinsip filsafat perennial, pertama percaya pada tingkat tertinggi transcendental dapat dilihat suatu hakekat kebenaran dalam berbagai bentuk kebenaran atau tradisi, kedua, dapat dilihat dalam bentuk seni tradisi mengandung prinsip kebenaran dan keindahan, dan ketiga kaum tradisional yakin bahwa kebudayaan, pemikiran dan peradaban modern adalah buruk karena tak berazaskan prinsip keagamaan dan keohanian dari (Ahmad 1994 dalam Susanto 2000).

Menurut Wylie terlepas dari penampilannya yang membumi, ilmu arkeologi selalu menjadi disiplin filosofis yang dalam, sebagaimana yang dianut oleh arkeolog Anglo-America. Sejauh ini arkeologi layak mendekat pada kefilsafatan sebagai "soul-searching," jiwa pencarian yang dialami telah berlangsung 30 tahun terakhir. Banyak yang menyarankan bahwa konsekuensi ini mewakili jeda waktu masa lalu, yang akan disambut sebagai pengetahuan berbasis penelitian yang akan menjadi kokoh atau hanya sekedar dogma-dogma atau pernyataan pasif tidak bermakna. Ataukah aktivitas penelitian arkeologi hanya sekedar pekerjaan yang kemudian menimbulkan sikap-sikap penyesalan, karena telah menandai hilangnya sesuatu yang indah dari masa lampau, atau suatu pengorbanan waktu yang sia-sia dan melelahkan sebagai penyelidikan yang pada akhirnya merupakan sesuatu yang tak terpecahkan dan ketidakpastian (Wylie 2002).

Arkeologi dapat digambarkan sebagai pengetahuan ilmiah yang filosofinya mendekati pada masalah-masalah yang mengarah pada perdebatanperdebatan antara masalah naturalisasi filsafat dan masalah sosial humanisme. Filsafat ilmunya pada studi ilmiah yang terintegasi dari berbagai bentuk ilmu penelitian empiris. Dimana sebagai subjek bahan bahasan penelitiannya sebagai praktek ilmiah dan berbagai macam pengetahuan kognitif, tingkah laku, sosial, institusi atau lembaga, dan kesejarahan suatu keadaan yang mungkin dapat didekati secara ilmiah. Pada intinya memberi penjelasan penolakan terhadap pendekatan Carnapian yang filsafatnya cenderung pada kebenaran yang berdiri sendiri. Ungkapan naturalisasi kefilsafatan berpedoman pada pertanyaan-pertanyaan filosofis, sebagai pertanyaan empiris tentang tujuan - tujuan, produksi informasi, dan alasan pengetahuan ilmiah yang muncul (Wylie 2002).

\section{Tafsir dari dua situs Cagar Budaya, Pemikiran Modern, dan Pemikiran Tradisional}

\section{Situs Lahaibara}

Situs ini merupakan bukti fisik atau material sebagai batas wilayah demarkasi teritorial adat antara warga Bulungan dengan daerah komunitas Dayak Hupan/Kayan. Persaudaraan ini diakui oleh kedua belah pihak, sehingga janji, komitmen dan sumpah harus ditepati. Konsekuensinya apabila melanggar bisa menimbulkan masalah, misalnya pertengkaran atau memudarnya persaudaraan. 
Akan tetapi hal yang lebih esensi sebagai bagi bangsa yang 'beradab' adalah pengingkaran janji adalah suatu kejahatan. Tekat untuk memegang janji, komitmen dan sumpah itu adalah kewajiban. Apabila hal ini dilanggar dapat membahayakan diri sendiri, dan bisa menghadirkan kesialan, atau malapetaka, dan siapa pun yang melanggar layak mendapat hukuman. Sebagai tradisi masyarakat adat hal ini tentu dijunjung tinggi dan memiliki aspek dedaktik yang tak lekang dimakan oleh zaman. Apa yang terjadi dengan Mayer? la merefleksikan manusia modern, la begitu marah terhadap 'priyayi Bulungan' dan aturan yang tak berpihak padanya dengan melampiaskan dengan pengerusakan batu tegak Lahaibara. Dan tentu ia tidak mempercayai tentang hal-hal mistis, tidak rasional yang berbau unsur non logika apalagi untuk patuh pada komitmen, janji, atau sumpah peraturan adat tersebut, yang dipandang tidak menguntungkan dirinya. Hal-hal demikian mungkin ia anggap sebagai suatu yang sia-sia, kebodohan dan tidak produktif. Dengan pengerusakan ini ia mengira tindakan tersebut akan melemahkan kepercayaan mistis setempat, di sisi lain menunjukkan sikap kesombongan dan rasionalitas mereka anut. Tidak lama setelah peristiwa itu, Mayer pun jatuh sakit dan akhirnya meninggal secara mengenaskan. Masyarakat modern tentu sulit menghubungkan pengerusakan batu tegak Lahaibara dengan peristiwa kematian Mayer. Tetapi, bagi masyarakat kuno, atau masyarakat tradisional kedua hal tersebut terkait dan orang yang berani melanggar komitmen, sumpah dan janji sudah sepantasnya mendapat hukuman. Unsur dedaktik kuno lebih mengena pada masyarakat sederhana dibanding manusia modern yang lebih rasional, tetapi kadang melanggar etika. Hukum etis berbeda dengan hukum positif cara kerja dan rasionalitasnya. Hukum positif walaupun ancaman hukuman lebih konkrit, tetapi tidak ada jaminan masyarakat untuk mentaati karena kadang ada proses yang tidak semestinya.

\section{Situs Makam Syeh Sayid Ahmad Al Mahgribi}

Situs ini perlu mendapat perhatian terutama berkaitan dengan proyek pembuatan jembatan di dekat situs yang saat ini mangkrak. Orang modern lebih percaya pada teknologi, daripada hal-hal yang berbau mistis atau agama yang menjadi sumber hukum etis di masyarakat. Secara teknis, kedua sisi jambatan tentu tidak berbeda jauh, mengingat daerah ini lebih dekat dengan muara dan pantai, sehingga kondisi tanah dan batu penyusun tidak keras. Secara geologis sulit dipercaya di daerah ini ada batuan yang sangat kuat dan kokoh. Target dan perhitungan teknis ternyata meleset dari perkiraan. Masyarakat modern lebih percaya hal-hal teknologi dan perhitungan di atas kertas, sedangkan masyarakat tradisional memilih menghormati keberadaan makam ulama atau orang yang memiliki otoritas moral, sekalipun mereka telah meninggal. Hal ini tidak lepas dari siapa yang dimakamkan. Pembangunan tiang pancang gagal direalisasikan, bukan karena masalah teknis, tetapi masyarakat tradisonal menghubungkannya dengan hal di luar masalah teknis, yaitu karena keberadaan makam ulama tersebut. Apalagi apabila mengingat perjuangan dari Syeh Ahmad Al Mahgribi yang berasal dari tempat yang sangat jauh, datang hanya untuk menyiarkan agama ke Bulungan. Masyarakat tradisional percaya bahwa beliau adalah tokoh yang memiliki kedudukan ilmu yang tinggi dalam hal agama, dan percaya seakan alam pun menghormatinya. Kepercayaan ini seakan telah diperingatkan sebelumnya, yaitu saat ia dimakamkan. Matahari pun seakan-akan menunggunya, tidak mau tenggelam sebelum prosesi pemakaman beliau selesai. Hubungan kausalitas ini pun sulit diterima logika modern. Misteri enigma ini sudah sekitar 10 tahun dan akan menjadi bahan perbincangan, serta di sisi lain menjadi daya tarik tersendiri.

Demikian menurut pandangan penulis melihat dua peninggalan di Kabupaten Bulungan, dan hal ini seakan memiliki implikasi kepada teori dan pemikiran yang berbeda dengan apa yang sudah dikemukakan sebelumnya. Penafsiran ini tentu bukan berarti suatu kebenaran, dan sisi lain masih banyak hal-hal yang masih perlu diperdebatkan. Penelitian arkeologi memiliki akar masalah yang hampir sama dengan permasalahan yang dihadapi oleh studi sejarah, dimana eksplanasi deduktifnomologis sulit diterapkan secara memadai. Alasannya antara lain karena satu penjelasan data eksplanasi deduktif-nomologis tidak pernah menjelaskan peristiwa secara utuh, sehingga mengabaikan kompleksitas peristiwa. Kedua, 
eksplanasi deduktif-nomologis sifat argumentasinya menekanan pada aspek formal validitas lebih diutamakan daripada kebenaran atau kesesuaian data empiris. Eksplanasi deduktif-nomologis hanya menekankan hukum umum, tidak memberi tempat kepada interpretasi yang sangat berguna dalam pemahaman fenomena historis. Sejarah atau peristiwa masa lalu itu sebenarnya hanya sekali terjadi, tokoh a berkomitmen, tokoh b meninggal, dan lain-lain adalah fenomena manusiawi yang sangat rumit, motif, tujuan dan kehendak manusia sulit untuk diramalkan.

Ahyar Lubis mengatakan bahwa ilmu pengetahuan yang sekarang berkembang telah kehilangan kepercayaan terhadap penggunaan akal budi atau rasio seperti logika Aristoteles yang menjadi fundasi utama pemikiran Barat. Filsafat Barat 'modernisme' diacukan pada pemikiran yang berkembang setelah Descartes yang mengasumsikan bahwa rasio sebagai satu-satunya dasar untuk memperoleh kebenaran. Rasio adalah subjek sebagai dasar bagi ilmu pengetahuan, sebagai dasar pengembangan kebudayaan serta penentu kepastian dan kebenaran. Descartes dan Imanuel Kant sangat berjasa bagi tegaknya budaya modern, berhasil menempatkan epistemologi sebagai ratu/mahkota filsafat, dimana masalah bahasa, etika, metafisika bahkan tentang ada tidak adanya Tuhan ditentukan oleh epistemologi. Hal ini kemudian dipertegas positifisme oleh August Comte dan tokoh positivisme logis (Robert Carnap) dengan menghapus metafisika dari wilayah filsafat dan ilmu pengetahuan (Ahyar Lubis 2003).

Lebih lanjut ditegaskan oleh Yusuf Ahyar Lubis dengan merangkum atas perkembangan dan posisi rasionalitas. Definisi konseptual yang menyebut 'manusia adalah makhuk rasional' sesungguhnya merupakan abstraksi, penyederhanaan dan membatasi. Setiap sistem pemikiran menciptakan batas-batas konseptualnya sendiri. Upaya pencarian kebenaran ilmiah para ilmuwan positifisme terbukti bersifat sementara dan konvensional. Bagaimana menghadapi berbagai serangan terhadap rasio, kebenaran objektif universal, serta bahasa sebagai cermin realitas. Para filsuf ilmu pengetahuan baru (pascapositivisme), seperti Thomas S. Kunh, Michel Polanyi, dan Paul Feyerabend telah mencoba untuk mengatasinya. Kuhn mengemukakan bahwa ilmu pengetahuan selalu dikontruksi di atas dasar paradigma ilmiah yang didukung oleh komunitas ilmuwan tertentu. Oleh karena itu, kebenaran ilmiah bersifat paradikmatik konvensional, karena paradigma ilmiah itu sendiri dapat berubah sesuai dengan perkembangan zaman. Jurgen Habermas, Marx Weber, Scot Lash menggunakan istilah 'modernisasi' sebagai proses diferensiasi budaya dan otomasi sosial atau mengotomatiskan suatu gerakan sosial, karena itu moderisasi dipahami sebagai dampak dari proses deferensiasi. Di bidang seni proses deferensiasi dan otonomi ini menimbulkan semboyan seni untuk seni, sejalan dengan pandangan bahwa ilmu pengetahuan demi ilmu pengetahuan itu sendiri. Polanyi mengemukakan bahwa dalam ilmu pengetahuan terdapat asumsi-asumsi ilmiah yang tersembunyi. Asumsi-asumsi itu pada umumnya tidak disadari. Feyerabend mengemukakan anti metode paradikma positivisme, demikian Yusuf Ayar Lubis mensarikannya (Ahyar Lubis 2003).

Kendekatan yang sesuai untuk mengurai dan memahami fenomena-fenomena tersebut di atas adalah filsafat perennial. Filsafat perennial dipandang dapat menjelaskan segala kejadian yang bersifat hakiki menyangkut kearifan yang diperlukan dalam menjalankan hidup yang benar yang menjadi hakekat dari seluruh agama dan tradisi-tradisi besar spiritualitas manusia. Situs pertama, 'peninggalan Lahaibara' dan sikap Mayer terkait dengan bagaimana seharusnya orang memegang tradisi, janji dan komitmen. Situs kedua, dapat dihubungankan variabel posisi makam ulama dengan posisi jembatan yang kurang menghargai atau bersikap layak bagaimana kepada ulama, seseorang yang memiliki otoritas moral dan seseorang yang pembawa prinsip hidup serta orang yang tulus dalam pengabdian.

Secara etimologis, perennial berasal dari bahasa latin, yaitu perrenis yang berarti kekal, abadi selama-lamanya. Filsafat perennial identik dengan filsafat keabadian (Kuswanjono 1997). Lebih lanjut dengan mengutip pendaat Frithjof Schuon, bahwa filsafat perennial merupakan metafisika yang mengakui realitas illahi yang bersifat subtansial bagi dunia benda-benda, hidup dan pemikiran; merupakan psikologi yang menemukan sesuatu 
yang sama di dalam jiwa bahkan identik dengan realitas illahi, merupakan etika yang menempatkan tujuan akhir manusia pada pengetahuan tentang dasar yang imanen maupun transenden. Menurut Huxley, unsur-unsur filsafat perennial dapat ditemukan pada tradisi bangsa primitif, dalam setiap agama dunia dan pada bentuk-bentuk yang berkembang pada setiap hal dari agama-agama yang lebih tinggi (Kuswanjono 1997).

Revolusi pemikiran ala Descartes mengajukan argumentasi epistimologis mengenai asal kebenaran adalah dari rasio, maka terjadi pemisahan antara manusia dengan hal-hal yang transenden. Manusia telah mengangap dirinya 'super being' yang mampu menyelesaikan seluruh persoalan yang dihadapi dengan akal dan rasionya serta menjadikan teknologi sebagai instrumen utama dalam mengatasi segala persoalan kehidupan manusia. Selanjutnya fenomena-fenomena kehidupannya terlepas dari dimensi spiritual dan tergantikan oleh pendekatanpendekatan positivistik-mekanik (Kuswanjono 1997). Meminjam istilah dari Nasr Husain Spiritual sebagai tidak lain dari mengetahui, mencintai dan taat kepada Tuhan. Kuswanjono memaknai spiritualitas adalah kebutuhan manusia masa kini dan sebagai kebutuhan permanen bagi manusia. Seseorang yang memiliki kualitas spiritualitas tinggi adalah seseorang yang merefleksikan Tuhan sebagai yang vital-utama, yang menentukan norma-norma dalam kehidupan sehari-hari.

Pada poin di UU Nomor 11 tahun 2010 tentang Cagar Budaya ini mengacu paradigma baru yang menguatkan dalam pelestarian diperlukan keseimbangan aspek-aspek; ideologis, akademis, ekologis, dan ekonomis guna meningkatkan kesejahteraan rakyat. Aspek ideologis menjadi penting, mengingat bahwa kebudayaan tidak lepas dari dunia ide-ide, gagasan-gagasan, pemikiranpemikiran yang pada akhirnya akan menggerakkan manusia untuk berbuat, sebagian menjadi pola perilaku dan hasil karya manusia, sebagai wujud bendawi yang dapat ditangkap oleh panca indra. Dalam tradisi Melayu, dan mungkin pada peninggalan-peninggalan keagamaan aspek hagiologis sangat kental. Hagiologis diartikan sebagai bacaan mengenai, riwayat hidup dan legenda orang-orang suci (Tim Pusat Bahasa 2008). Seperti halnya Wali Songo di Tanah Jawa, dengan
Masjid Demak-nya menjadi cerita menjelang tidur, tetapi peninggalan ini dibuat, sekaligus bagaimana nilai-nilai keagamaan ini diangkat.

Aspek ideologis ikut menjadi pertimbangan dalam usaha menata moralitas bangsa dalam arti yang luas. Benda cagar budaya tidak hanya dapat didekati dengan dunia akademis, tetapi tetap dan harus diupayakan berdampak pada kecerdasan akal untuk menghubungkan dan mengkorelasikan dengan nilai-nilai. Peninggalan-peningalan masa lalu, merupakan saksi dan bukti bagaimana orangorang dahulu berpikir, bertindak atau berperilaku dan menghasilkan karya serta bagaimana menghasilkan karya dari wujud ide-ide tersebut. Dengan bahasa lain, cagar budaya selain memiliki peran dalam dunia akademis, ekologis serta ekonomis juga dapat mengungkap ide-ide yang abstrak, yang akan merupakan aspek penting kehidupan manusia.

Nurhadi Magetsari mengatakan pada hekekatnya aspek pertama pengungkapan kembali "nilai lama adalah merupakan tujuan ilmu arkeologi". Adapun nilai lama itu diabstraksikan melalui peninggalan fisiknya atau wujud kebudayaan materi (Magetsari 2000). Lebih lanjut, maka melalui penerapan metodologinya arkeologi berupaya untuk mengungkapkan nilai itu kembali, serta kemudian melestarikan wujud fisiknya sebagai warisan atau cagar budaya. Magetsari selanjutknya dengan demikian, maka hasil yang dapat dicapai oleh arkeologi paling tidak mencakup dua hal. Pertama arkeologi dapat menghasilkan apa yang disebut cultural identity dan kedua, arkeologi dapat memerankan sebagai sarana pembentukan rasa kebangsaan (nation) (Magetsari 2000). Dari dua hal, yang telah desebutkan masih ada satu unsur lagi yang mungkin dapat ditambahkan, yaitu tentang apa yang disebut moralitas dan spiritualitas.

Darvil dalam karyanya Value system in Archeology menyatakan bahwa sumbangan sumberdaya yang mungkin dapat diberikan oleh peninggalan arkeologi mencakup banyak segi dan kategori-kategori yang beragam. Nilai kegunaan (use value), nilai-nilai pilihan, dan nilai-nilai keberadaanya. Pada kategori nilai kegunaan meliputi aspek-aspek: penelitian arkeologi, penelitian ilmiah ilmu lainnya, dunia kreatifitas seni, pendidikan, tempat rekeasi dan tujuan wisata, simbol-simbol keberadaan, sarana legitimasi, 
solidaritas sosial dan persatuan, serta peningkatan penghasilan devisa negara. Nilai-nilai pilihan meliputi pilihan tentang penguatan perubahan dan atau kesinambungan. Sumber daya arkeologi bukan saja sesuatu yang selalu diserahkan kepada para ilmuwan arkeologi, tetapi kadang dilanjutkan di untuk konfirmasi suatu hal mendasarkan pada bendera kebebasan akademik. Bukti arkeologi sering digunakan mendukung atau melegitimasi proposisi tententu, untuk meningkatkan solidaritas sosial dan mempromosikan integrasi sosal atau nilai keberadaan identitas budaya dan ketahanan dari perubahan (Darvill 1995). Satu lagi nilai yang langka nilai yang belum terungkap, potensi peninggalan arkeologi yang dipandang misteri atau yang menimbulkan pertanyaan-pertanyaan yang sulit dan seakan menjadi misteri abadi. Ketidaktahuannya tentang masa lalu mungkin sama penting atau bobotnya dengan mengetahuinya. Inilah apa yang disebut enigma (Darvill 1995). Misteri atau pertanyaan-pertanyaan ilmiah yang sering muncul di masyarakat, misalnya bagaimana stonehenge didirikan dan dibangun. Satu lagi nilai dari sumberdaya arkeologi adalah bertahan untuk tidak berubah mempertahankan tradisi lama. Setiap generasi percaya bahwa dunia sedang berubah secara tak terkendali dan lebih cepat dari sebelumnya. Mungkin ini benar. Tetapi tema utama protes terhadap perubahan adalah membangkitkan minat pada beberapa struktur atau institusi yang sebelumnya hampir tidak diperhatikan. Hal-hal seperti itu tidak akan dikenali sampai mereka terancam, tetapi kekuatan argumen untuk mempertahankannya adalah pengingat akan kekuatan laten dari nilai keberadaan. Terkait erat dengan gagasan menolak perubahan ini adalah gagasan tentang 'penegasan kembali dan validasi' Darvill mengutip apa yang dikemukakan oleh Lowenthal, 1985 dalam (Darvill 1995). Inti dari gagasan ini adalah preseden historis melegitimasi tindakan atas asumsi, eksplisit atau implisit, bahwa apa yang telah ada harus terus menjadi atau dipertahankan.

Van Peursen membagi kebudayaan menjadi tiga tahap, yaitu mistis, ontologis, dan fungsional. Tahap mistis, orang yang dikuasai oleh kekuatan diluar dirinya. Ontologis, tahapan manusia semacam usaha memahami dan pembebasan kekuatan magis. Sedang tahap fungsional, tahapan ini mengacu pada penggunaan, pemanfaatan alam lingkungan dunia sekitarnya (Peursen 1988). Tetapi apa yang dikemukakan terkait humanisme hal ini terus terjadi perdebatan yang tak pernah ada ujungnya. Cara pandang dan apa yang ditulis, didiskusikan dan dikemukakan disini mewakili sebuah seruan bahwa semua arkeolog tidak terlalu mempertentangkan sains dan humanisme. Keduanya memang berbeda, tetapi keduanya berhubungan dengan ilmu arkeologi. Arkeologi akan mendapat perhatian dan keuntungan dari kedua cara kerja yang berbeda baik yang subjektif maupun yang objektif. Sama halnya penerapan deduktifnomologikal dan yang tidak sepenuhnya menggunakan prinsip Hempelian ini dalam kerangka kerjanya. Peristiwa sejarah masa lampau, memang rumit, tidak sesederhana hukum-hukum alam yang bersifat universal.

\section{PENUTUP}

Ada beberapa peninggalan arkeologi yang menjadi pusat perhatian, karena memiliki kemisteriusan atau enigma. Apalagi situs atau objek arkeologi tersebut mengandung cerita, kisah atau kepercayaan. Untuk menuju kepada sebuah simpulan tentang tinggalan arkeologi yang demikian tidaklah mudah, karena hal ini seakan-akan merangkai pecahan-pecahan puzzle yang memerlukan waktu untuk dihimpun. Wylie menyarankan; sebagai studi ilmiah arkeologi harus bersifat membumi, dan memiliki disiplin filosofis yang mendalam, mendekatkan pada masalah-masalah naturalisasi filsafat dan masalah sosial humanisme. Namun demikian hal ini dapat sebagai alternative, selain pendekatan positivistik yang dapat dipandang lebih ilmiah yang mengacu kepada metode ilmu alam.

Peninggalan arkeologi selain memiliki dimensi fisik sekaligus mengandung dimensi abstrak berupa ide-ide atau pengetahuan. Latarbelakangnya dapat berupa legenda, mitos, cerita kemisteriusan atau enigma. Pada saat ini seakan-akan terbukti kembali atau informasi kuno tersebut terulang, yang ditegaskan dengan meninggalkan bukti fisik. Peninggalan dan bukti tentang kisah batu tegak Lahaibara dan kisah Mayer, makam Habib Ahmad Al 
Maghribi dengan jembatan yang pembangunannya terhenti lama merupakan bukti arkeologis yang tak terbantahkan, di mana sebelumnya telah memiliki larangan, peringatan atau suatu pantangan yang terkait dengan pengetahuan dan ide-ide normatif. Ada sebuah pendekatan yang lebih sesuai untuk mengurai dan memahami fenomena-fenomena tersebut dengan apa yang disebut filsafat perennial, yang menjelaskan tentang kearifan yang diperlukan dalam menjalani hidup, yang menjadi hakekat dari seluruh agama dan tradisi-tradisi besar spiritualitas manusia.

Situs pertama berupa peninggalan batu tegak Lahaibara terkait dengan nasib orang yang mengingkari janji atau komitmen. Seakan ada pesan tak tertulis, bagaimana orang harus memegang kesepakatan, janji atau komitmen. Situs kedua, makam tokoh dapat dihubungankan dengan aspek kelayakan posisi jembatan dan sikap penghormatan. Dengan posisi jembatan yang demikian seakan ada kesan kurang menghargai atau bersikap kurang layak sebagaimana kita bersikap kepada makam seorang ulama, seseorang yang memiliki otoritas moral, pembawa prinsip hidup serta kepada orang yang tulus dalam pengabdian.

Melalui metode observasi fisik, arkeologi berusaha 'membaca' dan menjelaskan sekaligus memahami sejarah pemikiran manusia. Dengan dibantu cara berpikir holistik kefilsafatan ini kita mendekati persoalan bahwa moralitas dan spritualitas dapat terbangun dengan cara berpikir ilmiah, sekaligus humanis melalui kajian arkeologi.

\section{DAFTAR PUSTAKA}

Ahmad, Baharuddin. 1994. Tradisionalisme Islam dalam Islam dan Dialog Budaya. Jakarta: Puspa Swara.

Ahyar Lubis, Yusuf. 2003. Masihkah Ada Tempat Untuk IImuwan. Depok: Akademika Press.

Atmojo, Bambang Sakti Wiku. 2000. Penelitian Arsitektur Makam Raja-raja di Wilayah Kalimantan Timur II, Kabupaten Berau Bulungan. Banjarbaru: Balai Arkeologi Banjarmasin.

Bulungan, Zarkasyi Van. 2010. "Study Awal Riwayat Syekh Ahmad Al-Magribi; Wali Allah Dari Bulungan." 2010 1. Diunduh 2 Oktober 2020 (http://muhzarkasybulungan.blogspot.com/201 0/10/syekh-ahmad-al-magribi.html).

Darvill, Timothy. 1995. "Value Systems in Archaeology." HIm. 40-49 dalam Managing Archaeology. London: Rouledge.

Fagan, Brian M. 1991. In the Bigining: An Introduction to Archaeology. Boston-Toronto: Litle, Brown and Company.

Kuswanjono, Arqom. 1997. "Filsafat Perennial Dan Rekonstruksi Pemahaman Keberagaman." Jurnal Filsafat Edisi Khusus: 95-108.

Magetsari, Nurhadi. 2000. "Nilai Lama Menatap Masa Depan." Dalam Proceeding EHPA di Bedigul "Mencermati Nilai Budaya Masa Lalu dalam Menatap Masa Depan." Jakarta: Proyek Peningkatan Penelitian Arkeologi.

Montana, Swedi. 1988. "Studi Perbandingan Naskah Islamologi Tentang Orang-orang Keramat Pada Zaman 'Kuwalen' Di Jawa." Berkala Arkeologi 9(1):38-63.

Pamardiningtyas, Sih Mangerti. 2019. Materialisme dan Agama. Surabaya: Universitas Airlangga.

Peursen, C. A. Van. 1988. Strategi Kebudayaan. Yogyakarta: Kanisius.

Rusdi. 2013. "Filsafat Idealisme (Implikasinya dalam

Pendidikan)." Jurnal Dinamika IImu 3(2): 236249.

Samsuri. 2003. "Bahasa Positivisme Logis dan Maknanya Bagi Agama: Kajian Pemikiran Rudolf Carnap." Jurnal Millah 3(1):133-242.

Santoso, Heri, dan Cuk Ananta Wijaya. 2003. "Kritik Atas Eksplanasi Deduktif-Nomologis dalam Ilmu Sejarah." Jurnal Filsafat 13(1):1-14.

Sharer, Robert J. 2003. Archaeology Discovering Our Past. California: Riverside.

Subroto, P.1982. "Arkeologi: Humanisme dan Sains." Berkala Arkeologi 3(1):6-13.

Susanto, Nugroho Nur. 2000. "Persinggungan Tradisionalisme dalam Arkeologi." Naditira Widya (5):78-84.

Susanto, Nugroho Nur. 2012a. Eksplorasi 
Peninggalan Arkeologi Daerah Aliran Sungai Kayan/Sungai Bulungan. Banjarbaru: Balai Arkeologi Banjarmasin.

Susanto, Nugroho Nur. 2012b. "Pengaruh Budaya Luar Terhadap Perkembangan Masyarakat Bulungan: Studi Pendahuluan." Naditira Widya 6(2):117-29.

Thomas, Julians. 2004. Archaeology and Modernity. London and New York: Routledge.

Tim Pusat Bahasa. 2008. Kamus Besar Bahasa Indonesia. Jakarta: Balai Pustaka.

Verhaak, C. Haryono Imam. 1991. "Filsafat IImu
Pengetahuan." Jakarta: Gramedia.

William J. Mayers- Oakes. 1989. "Science, Service and Stewardiship- A Basis for the Ideal Archaeology of the Future." Pp. 52-58 in One world Archaeology -9. Archaeological Heritage Management in the Modern World, edited by H.F. Cleere. London: Unwin Hyman.

Wylie, Alison. 2002. Thinking from Things: Essays In Philosopphy of Archaeology. London: University of California Press, Berkeley Los Angels. 